\title{
Predatory activity of Butlerius nematodes and nematophagous fungi against Haemonchus contortus infective larvae
}

\author{
Atividade predatória de nematóides Butlerius e fungos nematófagos \\ contra larvas infectantes de Haemonchus contortus
}

Manoel Eduardo da Silva ${ }^{1 *}$; Miguel Angel Mercado Uriostegui' ${ }^{2}$ Jair Millán-Orozco ${ }^{2}$; Pedro Mendoza de Gives²; Enrique Liébano Hernández ${ }^{2 \dagger}$; Fabio Ribeiro Braga ${ }^{3}$; Jackson Victor de Araújo ${ }^{4}$

\author{
${ }^{1}$ Campo Experimental de Pitangui, Empresa de Pesquisa Agropecuária de Minas Gerais - EPAMIG, Pitangui, MG, Brasil \\ ${ }^{2}$ Instituto Nacional de Investigaciones Forestales, Agricolas y Pecuarias, Jiutepec, México \\ ${ }^{3}$ Universidade Vila Velha - UVV-ES, Vila Velha, ES, Brasil \\ ${ }^{4}$ Departamento de Veterinária, Universidade Federal de Viçosa - UFV, Viçosa, MG, Brasil
}

Received June 21, 2016

Accepted August 23, 2016

\begin{abstract}
The purpose of this study was to evaluate the predatory activity of the nematode Butlerius spp. and fungal isolates of Duddingtonia flagrans, Clonostachys rosea, Arthrobotrys musiformis and Trichoderma esau against $H$. contortus infective larvae $\left(\mathrm{L}_{3}\right)$ in grass pots. Forty-eight plastic gardening pots containing $140 \mathrm{~g}$ of sterile soil were used. Panicum spp. grass seeds $(200 \mathrm{mg}$ ) were sown into each pot and individually watered with $10 \mathrm{~mL}$ of tap water. Twelve days after seeding, the pots were randomly divided into 6 groups $(\mathrm{n}=8)$. Two thousand $H$. contortus infective larvae $\left(\mathrm{L}_{3}\right)$ were added to each group. Additionally, the following treatments were established: Group $1-2000$ Butlerius spp. larvae; group $2-$ A. musiformis ( $1 \times 10^{7}$ conidia); group $3-$ T. esau $\left(1 \times 10^{7}\right.$ conidia); group $4-C$. rosea $\left(1 \times 10^{7}\right.$ conidia), group $5-D$. flagrans $\left(1 \times 10^{7}\right.$ conidia $)$ and Group 6 - no biological controller (control group). The larval population of $H$. contortus exposed to Butlerius spp. was reduced by $61.9 \%$. Population reductions of $90.4,66.7,61.9$ and $85.7 \%$ were recorded in the pots containing $A$. musiformis, T. esau, C. rosea and D. flagrans, respectively. The results of this study indicate that the predatory nematode Butlerius spp. and the assessed fungi display an important predatory activity can be considered suitable potential biological control agents.
\end{abstract}

Keywords: Biological control, nematodes, Duddingtonia flagrans, Clonostachys rosea, Arthrobotrys musiformis, Haemonchus contortus.

\section{Resumo}

O objetivo deste estudo foi avaliar a atividade predatória do nematoide Butlerius spp. e isolados fúngicos de Duddingtonia flagrans, Clonostachys rosea, Arthrobotrys musiformis e Trichoderma esau contra larvas infectantes ( $\mathrm{L}_{3}$ ) de Haemonchus contortus em vasos plantados com Panicum spp. Foram utilizados quarenta e oito potes plásticos de jardinagem contendo $140 \mathrm{~g}$ de solo estéril, $200 \mathrm{mg}$ de sementes de Panicum spp.. Cultivar coloniáo, foi semeado em cada vaso e, diariamente, molhados com $10 \mathrm{~mL}$ de água da torneira. Doze dias após, os vasos foram divididos em 6 grupos $(\mathrm{n}=8)$, e duas mil $\mathrm{L}_{3}$ de $H$. contortus foram adicionadas a cada vaso. Foram estabelecidos os seguintes tratamentos: Grupo 1 - 2.000 larvas de Butlerius spp.; Grupo 2 - A. musiformis ( $1 \times 10^{7}$ conídios); grupo 3 - T. esau ( $1 \times 10^{7}$ conídios); grupo 4 - C. rosea ( $1 \times 10^{7}$ conídios); grupo 5 - D. flagrans ( $1 \times 10^{7}$ conidia); e Grupo 6 - somente $\mathrm{L}_{3}$ de $H$. contortus que serviu como controle negativo. A população de $\mathrm{L}_{3}$ de $H$. contortus expostas a Butlerius spp. foi reduzida em 61,9\%. Redução populacional de 90,4, 66,7, 61,9 e 85,7\% foram observadas nos vasos contendo $A$. musiformis, T. esau, C. rosea e $D$. flagrans, respectivamente. Os resultados deste estudo indicaram que o nematoide Butlerius spp. e os fungos avaliados exibiram importante atividade predatória e podem ser considerados como agentes de controle biológico.

Palavras-chave: Controle biológico, nematóides, Duddingtonia flagrans, Clonostachys rosea, Arthrobotrys musiformis, Haemonchus contortus.

\footnotetext{
*Corresponding author: Manoel Eduardo da Silva. Campo Experimental de Pitangui - CEPI, Empresa de Pesquisa Agropecuária de Minas Gerais EPAMIG, Zona Rural, CEP 35650-000, Pitangui, MG, Brasil.

e-mail: manoelsilva@epamig.br

$\dagger$ In Memoriam
} 
Haemonchus contortus is considered one of the most important gastrointestinal parasitic nematodes due to its hematophagic habits and its high prevalence and pathogenicity (ROEBER et al., 2013). Massive infections of this parasite cause the death of animals, especially young ones, which are more susceptible (GILLEARD, 2013). This and other parasites are normally controlled with chemical anthelmintic drugs (TAYLOR et al., 2013). This method helps to reduce the parasitic burden in the animals, but it has some disadvantages, including the imminent emergence of anthelmintic resistance in the parasites (MÁRQUEZ-LARA, 2003; FORTES et al., 2013). This situation a serious problem to animal health because it diminishes the efficacy of anthelmintics, and new reports of anthelmintic resistance are being recorded every year (KLAUCK et al., 2014).

Biological control using natural nematode antagonists has gained increasing attention in recent decades (WANG et al., 2014). Some species of the genus Trichoderma (Hypocreales, Hypocreaceae), which are considered important nematode bio-regulator, can be used on agricultural soils without causing environmental problems (MARTÍNEZ et al., 2013). Other genera/species of fungi such as Clonostachys rosea (Hypocreales, Bionectriaceae) are considered mycoparasites that produce invasive hyphae, nematicidal toxins and induce resistance in their hosts (SCHROERS, 2001; COSTA et al., 2012).

On the other hand, the ascomycete Duddingtonia flagrans (Helotiales, Orbiliaceae) produces resistant resting spores (i.e., chlamydospores) that are able to survive after being orally administered to animals. Once these spores are expelled to the soil through the animal deposition's, they germinate in situ and develop trapping devices that capture nematode larvae recently hatched from nematode eggs and eventually feed on them (MENDOZA-de-GIVES \& TORRES-ACOSTA, 2012). Recent studies have demonstrated that the use of sodium alginate pellets as a vehicle for D. flagrans and Monacrosporium thaumasium (Helotiales, Orbiliaceae) can be considered a suitable tool for the control of cattle parasites (SILVA et al., 2014). Arthrobotrys species (Helotiales, Orbiliaceae) are probably the most extensively studied nematophagous fungi worldwide. They show a remarkable ability to form three-dimensional adhesive traps that produce substances which paralyze nematodes, facilitating their capture and destruction (EPE et al., 2008).

Butlerius spp. and other nematodes of the group Diplogasteridae are considered predators of nematode species (GAUGLER \& BILGRAMI, 2004). They inhabit decomposing organic matter, are prolific and resistant to adverse conditions, and are considered possible biological control agents of parasitic nematodes in nature (KHAN \& KIM, 2007). The focus of this study was to evaluate the predatory activity of Butlerius spp. and different genera/species of nematophagous fungi, including D. flagrans, C. rosea, Arthrobotrys musiformis and T. esau in pots containing Panicum spp. grass against H. contortus infective larvae (L3) kept under outdoor conditions.

The following genera/species of nematophagous fungi were used: D. flagrans (FTHO-8 strain); A. musiformis (Am-1 strain) and T. esau (Te-1 strain). These three strains belong to the Centro Nacional de Investigación Disciplinaria - CENID - Parasitología Veterinaria, INIFAP collection, Mexico; while C. rosea (Yucatán strain) was provided by the Centro de Investigación Científica de Yucatán (CICY-CONACYT, Mexico). All the fungi were maintained on $2 \%$ water agar plates.

The Butlerius spp. strain (called Tres Marías strain) was used. This strain, which belongs to the CENID-PAVET-INIFAP collection in Jiutepec, Morelos, Mexico, was obtained from an area of undisturbed woodland near the village of Tres Marías in the state of Morelos, Mexico (LIERANDI-JUÁREZ \& MENDOZA-DE-GIVES, 1998).

A $H$. contortus strain originally obtained from a naturally infected sheep at "Las Margaritas" farm (Hueytamalco, Puebla, Mexico) was used. The infective larvae $\left(\mathrm{L}_{3}\right)$ of this parasite were obtained from an egg donor sheep previously infected with the parasite LIERANDI-JUÁREZ \& MENDOZA-DE-GIVES, 1998). Thereafter, the donor animal was kept under suitable conditions to prevent further infection with gastrointestinal nematodes, GIN. Fecal cultures from this sheep were prepared in plastic containers and mixed with polystyrene particles and were maintained under laboratory conditions $\left(26,5^{\circ} \mathrm{C}\right)$ for six days. Infective larvae were extracted from fecal cultures using the Baermann technique (VALCARCEL SANCHO, 2009) and identified according to the descriptions of Keith (1953).

Forty-eight $90 \times 65 \mathrm{~mm}$ plastic gardening pots were used. One hundred and forty grams of sterile (autoclaved) nursery soil were placed in each pot. Two hundred milligrams of commercial Panicum spp (colonião). grass seeds (containing approximately 50 seeds) were added to each pot and watered daily with $10 \mathrm{~mL}$ of tap water for 12 days. After the pots were filled with grown grass, they were randomly divided into six groups of 8 pots each, and $2000 \mathrm{H}$. contortus infective larvae were added to each pot.

The predatory microorganisms used in the present study were used into an aqueous suspension and they were sprayed on the experimental pots as follows: Group $1-2000$ Butlerius spp. larvae; Group $2-1 \times 10^{7} \mathrm{~A}$. musiformis conidia/chlamydospores; Group $3-1 \times 10^{7}$ T. esau conidia; Group $4-1 \times 10^{7}$ C. rosea conidia, and Group $5-1 \times 10^{7}$ D. flagrans chlamydospores; Group 6-contained only the parasitic larvae and served as negative control. The pots were placed outdoors in an area of native grass, where they were exposed to the weather and watered daily with $10 \mathrm{~mL}$ of top water for 12 days. Meteorological data, i.e., ambient temperature, rainfall and relative humidity, were recorded.

After 12 days, the larvae were extracted from the entire content of each pot, using a Baermann funnel for $24 \mathrm{~h}$, and were quantified. The results are expressed based on the mean number of live larvae recovered from each treatment. The larvae extracted from the control group were considered 100\% live larvae, and were used to estimate the mortality rate.

The data were analyzed by ANOVA, the mean number of recovered larvae were compared among groups using the BioEstat 5.0 program, and Tukey test at $\mathrm{P}<0.05$ was used as a complementary test.

Table 1 lists the mean and standard deviation of the number of $H$. contortus $\mathrm{L}_{3}$ recovered from the pots, and the percent reduction in the larvae population attributable to the nematode-predatory nematode Butlerius and to the different genera/species of nematophagous fungi. The results indicate that the $61.9 \%$ reduction in the $H$. contortus larvae population is attributable to the predatory activity of Butlerius spp. The nematophagous fungi showed the following 
Table 1. Mean and standard deviation of Haemonchus contortus infective larvae $\left(\mathrm{L}_{3}\right)$ recovered from Panicum spp. grass pots after 12 days of interaction with Butlerius spp. and with different nematophagous fungi kept outdoors, and percent reduction caused by the different antagonists of nematodes.

\begin{tabular}{lcccccc}
\hline & Butlerius sp. & A. musiformis & T. esau & C. rosea & D. flagrans & Control \\
\hline Means & $40(20) \mathrm{a}$ & $10(17.32) \mathrm{a}$ & $35(78.58) \mathrm{a}$ & $40(28.28) \mathrm{a}$ & $15(19.36) \mathrm{a}$ & $105(39.69) \mathrm{b}$ \\
Reduction & $61.90 \%$ & $90.40 \%$ & $66.70 \%$ & $61.90 \%$ & $85.70 \%$ & $0 \%$ \\
\hline
\end{tabular}

Note: Different letters indicate a statistical difference $(\mathrm{p}<0.05)$.

population reductions: A. musiformis (90.4\%), T. esau (66.7\%), C. rosea $(61.9 \%)$ and D. flagrans $(85.7 \%)(\mathrm{p}<0.05)$. No statistical difference was found in the predatory activity of the different nematode antagonists ( $p>0.05$ ). The following meteorological data were recorded during the experiment: Temperature $23.6^{\circ} \mathrm{C}$ $\left(16-32^{\circ} \mathrm{C}\right)$, relative humidity $53 \%(27.2-68.9 \%)$ and average daily rainfall $6.4 \mathrm{~mm}$. These environmental conditions are favorable for good larval development (HERNÁNDEZ, 2011) and also for nematophagous fungi (DHINGRA \& SINCLAIR, 2005). The highest fungal efficacy $(90.4 \%)$ was exhibited by A. musiformis. Assessing the predatory capability of predatory nematodes i.e., Butlerius sp. and nematophagous fungi like the ones used in the present study is crucial to future works focused to find an sustainable alternative method of control that helps to reduce the nematode populations like $H$. contortus and perhaps other parasites of importance in the sheep and goat industry. This result is similar to that found by Graminha et al. (2005), who reported a $94.4 \%$ reduction in $H$. contortus larvae in sheep feces using a local strain of $A$. musiformis from Brazil.

Acevedo-Ramírez et al. (2011) also reported 50\% reduction in $H$. contortus larvae in vitro, using a Mexican strain of $A$. musiformis. On the other hand, Chauhan et al. (2005) observed that A. musiformis and $D$. flagrans significantly reduced the population of $H$. contortus larvae in feces after it was orally administered to sheep and passed through the gastrointestinal tract. Similarly, D. flagrans chlamydospores reduced the larvae population of trichostrongylidae by $95 \%$ after passing through the gastrointestinal tract of sheep (CRUZ et al., 2008).

Nematophagous fungi are also being assessed against plant-parasitic nematodes, i.e., $85 \%$ reduction rates of Meloidogyne javanica $\left(\mathrm{J}_{2}\right)$ in tomato plants using Arthrobotrys sp., and 25\% reduction in egg viability and $74 \%$ reduction in $\mathrm{J}_{2}$ have been recorded using Trichoderma harzianum (JAMSHIDNEJAD et al., 2013). On the other hand, the $C$. rosea strain used in this study led to a $61.9 \%$ reduction in $H$. contortus larvae $\left(\mathrm{L}_{3}\right)$, which is similar to the results reported by Jiménez (personal communication by Jiménez, S.R., 2013), who found reduction rates of 84.2 and $59.5 \%$ by C. rosea (Yucatán strain) and Clonostachys sp. (Campeche strain), respectively. Similar results were reported by Baloyi et al. (2011), who recorded reduction rates of 69.9 and $89.3 \%$ in the number of trichostrongylidae larvae using two $C$. rosea strains. In another study involving sheep feces and water, reduction rates of 71.9, 94.7, 92.7, 100 and 87.7\% were recorded for Rhabditis sp., C. elegans, P. redivivus, Butlerius sp. and $H$. contortus, respectively (personal communication by Martínez, R.R., 2011).

The main prerequisite for the use of biocontrol agents is without doubt their 'ability to colonize the external environment in large amounts', and to provide an environmental decrease in the infecting free forms of target nematodes (BRAGA \& ARAÚJO, 2014). In this sense, the predatory nematode Butlerius spp., as well as the different nematophagous fungi assessed here, namely, A. musiformis, T. esau, C. rosea and D. flagrans, reduced the population of infective $H$. contortus larvae in gardening pots maintained under outdoor conditions. This study provides evidence of the predatory activity of the nematode-predatory nematode Butlerius spp. and of four nematophagous fungi strains in reducing the $H$. contortus (L3) population in Panicum spp. grass pots under outdoor conditions. These organisms can therefore be considered potential candidates for the biological control of sheep haemonchosis in further studies.

\section{Acknowledgements}

The authors wish to thank Dr. Anwar L. Bilgrami of the Department of Mosquito Control, USDA, Maryland, USA for his values support in the taxonomic identification of Butlerius spp. and Dr. Marcela Gamboa of CICY-Yucatán, Mexico for kindly providing the Clonostachys rosea strain used in this study. The authors also acknowledge the Brazilian research funding agencies $\mathrm{CNPq}$ (National Council for Scientific and Technological Development), CAPES (Federal Agency for the Support and Improvement of Higher Education) FAPEMIG (Minas Gerais State Research Foundation) and FAPES (Espirito Santo Sate Research Foundation) for their financial support and award of a grant

\section{References}

Acevedo-Ramírez PMC, Quiroz-Romero H, Valero-Coss RO, Mendozade-Gives P, Gómez JL. Nematophagous fungi from Mexico with activity against the sheep nematode Haemonchus contortus. Rev Ibero-Latinoam Parasitol 2011; 70(1): 101-108.

Baloyi MA, Laing MD, Yobo KS. Isolation and in vitro screening of Bacillus thuringiensis and Clonostachys rosea as biological control agents against sheep nematodes. Afr J Agric Res 2011; 6(22): 5047-5054.

Braga FR, Araújo JV. Nematophagous fungi for biological control of gastrointestinal nematodes in domestic animals. Appl Microbiol Biotechnol 2014; 98(1): 71-82. PMid:24265027. http://dx.doi.org/10.1007/ s00253-013-5366-z.

Chauhan JB, Sanyal PK, Subramanian RB. The nematode-trapping efficacy of two chlamydospore-forming fungi against Haemonchus contortus in sheep. J Helminthol 2005; 79(4): 315-319. PMid:16336714. http:// dx.doi.org/10.1079/JOH2005291.

Costa LB, Rangel DEN, Morandi MAB, Bettiol W. Impact of UV-B radiation on Clonostachys rosea germination and growth. World JMicrobiol Biotechnol 2012; 28(7): 2497-2504. PMid:22806155. http://dx.doi. org/10.1007/s11274-012-1057-7. 
Cruz DG, Cordeiro RC, Lopes AJ, Rocha LV, Santos CP. Comparison of the efficacy of different isolates of the nematode-trapping fungi Arthrobotrys spp. and Duddingtonia flagrans in reducing infective larvae of nematodes after passage through the digestive tract of sheep. Rev Bras Parasitol Vet 2008;17(Suppl 1): 133-137. PMid:20059832.

Dhingra OD, Sinclair JB. Basic plant pathology methods. 2nd ed. Boca Raton: CRC Press, 2005.

Epe C, Holst C, Koopmann R, Schnieder T, Larsen M, von SamsonHimmelstjerna G. Investigation on the influence of nematophagous fungi as feed additive on nematode infection risk of sheep and goats on pasture. Agricul Forestry Res 2008; 58(3): 191-202.

Fortes FS, Kloster FS, Schafer AS, Bier D, Buzatti A, Yoshitani UY, et al. Evaluation of resistance in a selected field strain of Haemonchus contortus to ivermectin and moxidectin using the Larval Migration on Agar Test. Pesqui Vet Bras 2013; 33(2): 183-187. http://dx.doi.org/10.1590/S0100736X2013000200008.

Gaugler R, Bilgrami AL. Feeding behaviour. In: Gaugler R, Bilgrami AL. Nematode behaviour. New Jersey: CABI Publishing, 2004. p. 91-126.

Gilleard JS. Haemonchus contortus as a paradigm and model to study anthelmintic drug resistance. Parasitology 2013; 140(12): 1506-1522. PMid:23998513. http://dx.doi.org/10.1017/S0031182013001145.

Graminha EBN, Monteiro AC, Silva HC, Oliveira GP, Costa AJ. Controle de nematóides parasitos gastrintestinais por Arthrobotrys musiformis em ovinos naturalmente infestados mantidos em pastagens. Pesq Agropec Bras 2005; 40(9): 927-933. http://dx.doi.org/10.1590/ S0100-204X2005000900013.

Hernández EL. Ecología de larvas de nematodos gastrointestinales de bovinos, ovinos y caprinos. In: Romero EQ, Castillo JAF, Velarde FI, Arellano MEL, editors. Epidemiología de enfermedades parasitarias en animales domésticos. México: Inifap, 2011. p. 254-272.

Jamshidnejad V, Sahebani N, Etebarian H. Potential biocontrol activity of Arthrobotrys oligospora and Trichoderma harzianum $\mathrm{BI}$ against Meloidogyne javanica on tomato in the greenhouse and laboratory studies. Arch Phytopathol Plant Protect 2013; 46(13): 1632-1640. http://dx.doi.org/1 0.1080/03235408.2013.778476.

Keith RK. The differentiation of infective larvae of some common nematode parasites of cattle. Aust J Zool 1953; 1(2): 223-235. http:// dx.doi.org/10.1071/ZO9530223.

Khan Z, Kim HY. A review on the role of predatory soil nematodes in the biological control of plant parasitic nematodes. Appl Soil Ecol 2007; 35(2): 370-379. http://dx.doi.org/10.1016/j.apsoil.2006.07.007.
Klauck V, Pazinato R, Lopes LS, Cucco DC, Lima HL, Volpato A, et al. Trichostrongylus and Haemonchus anthelmintic resistance in naturally infected sheep from southern Brazil. An Acad Bras Cienc 2014; 86(2): 777-784. http://dx.doi.org/10.1590/0001-3765201420130061.

Llerandi-Juárez RD, Mendoza-de Gives P. Resistance of chlamydospores of nematophagous fungi to the digestive processes of sheep in Mexico. J Helminthol 1998; 72(2): 155-158. http://dx.doi.org/10.1017/ S0022149X00016345.

Márquez-Lara D. Resistencia a los antihelmínticos: origen, desarrollo y control. Rev Corpoica 2003; 4(1): 55-71.

Martínez B, Infante D, Reyes Y. Trichoderma spp. y su función en el control de plagas en los cultivos. Rev Proteccion Veg 2013; 28(1): 1-11.

Mendoza-de-Gives P, Torres-Acosta F. Biotechnological use of Fungi in the control of ruminant parasitic nematodes. In: Arias MS, Paz-Silva A. Fungi: types, environmental impact and role in disease. New York: Nova Editorial; 2012. p. 389-408.

Roeber F, Jex AR, Gasser RB. Impact of gastrointestinal parasitic nematodes of sheep, and the role of advanced molecular tools for exploring epidemiology and drug resistance - an Australian perspective. Parasit Vectors 2013; 6(1): 153. PMid:23711194. http://dx.doi.org/10.1186/1756-3305-6-153.

Schroers HJ. A monograph of Bionectria (Ascomycota, Hypocreales, Bionectriaceae) and its Clonostachys anamorphs. Stud Mycol 2001; 46: 1-214.

Silva ME, Braga FR, Borges LA, Oliveira JM, Lima WS, Guimarães MP, et al. Evaluation of the effectiveness of Duddingtonia flagrans and Monacrosporium thaumasium in the biological control of gastrointestinal nematodes in female bovines bred in the semiarid region. Vet Res Commun 2014; 38(2): 101-106. PMid:24477840.

Taylor CM, Wang Q, Rosa BA, Huang SCC, Powell K, Schedl T, et al. Discovery of Anthelmintic Drug Targets and Drugs Using Chokepoints in Nematode Metabolic Pathways. PLoS Pathog 2013; 9(8): e1003505. PMid:23935495. http://dx.doi.org/10.1371/journal.ppat.1003505.

Valcarcel Sancho, F. Atlas de parasitología ovina. España: S. L. Servet Diseño y Comunicación; 2009.

Wang W, Meng Q, Qiao J, Wang J, Yang L, Luo J, et al. Isolation of Arthrobotrys oligospora from soil of the Chinese Northern Tianshan Mountain slope pasture show predatory ability against Haemonchus contortus larvae. Biocontrol Sci Technol 2014; 24(2): 170-179. http:// dx.doi.org/10.1080/09583157.2013.853727. 